\title{
Transcultural adaptation to Portuguese of the Mind Excessively Wandering Scale (MEWS) for evaluation of thought activity
}

\author{
Adaptação transcultural da Mind Excessively Wandering Scale para avaliação de \\ atividade mental
}

Tiago Figueiredo, ${ }^{1,2}$ Pilar Erthal, ${ }^{2}$ Dídia Fortes, ${ }^{1,2}$ Phillip Asherson, ${ }^{3}$ Paulo Mattos ${ }^{1,2}$

\begin{abstract}
Introduction: The concept of mind wandering refers to periods during which attention and content of thoughts depart from the original idea or activity being performed. The phenomenon occurs commonly in the general population and the Mind Wandering Excessively Scale (MEWS) evaluates its frequency, intensity and related negative outcomes.

Objective: To describe the cross-cultural adaptation of the MEWS.

Methods: Cross-cultural adaptation of the original scale followed five consecutive steps: translation, backtranslation, appreciation of semantic equivalence and administration to a convenience sample to 20 adults with attention deficit hyperactivity disorder (ADHD) and 20 normal controls.

Results: Results indicated a satisfactory equivalence between the original and translated versions. A synthesis version for Brazilian Portuguese is presented.

Conclusions: MEWS provides information on thought activity, which is particularly important in ADHD cases. The Brazilian Portuguese version would be welcome to address specific treatment responses and obtain new outcome measures

Keywords: ADHD, mind wandering, attention.
\end{abstract}

\section{Resumo}

Introdução: $O$ conceito de devaneio se refere a períodos nos quais a atenção e o conteúdo do pensamento de distanciam da ideia original ou da atividade que estava sendo realizada. O fenômeno ocorre na população em geral, e a Escala Mind Excessively Wandering Scale (MEWS) avalia sua frequência, intensidade e desfechos negativos associados.

Objetivos: Descrever a adaptação transcultural da MEWS.

Métodos: A adaptação transcultural envolveu cinco etapas: tradução, retrotradução, apreciação da equivalência semântica e administração em amostra de conveniência composta de 20 adultos com transtorno do déficit de atenção com hiperatividade (TDAH) e 20 controles normais.

Resultados: Os resultados demonstraram equivalência satisfatória entre as versões original e traduzida. Uma versão síntese para o português brasileiro é apresentada.

Conclusão: A MEWS fornece informações importantes sobre atividade mental, algo particularmente importante em casos de TDAH. A versão em português brasileiro deverá ser bem acolhida, permitindo investigar respostas específicas ao tratamento e obter novas medidas de desfechos.

Descritores: TDAH, devaneio, atenção.

\footnotetext{
${ }^{1}$ Instituto de Psiquiatria, Universidade Federal do Rio de Janeiro (UFRJ), Rio de Janeiro, RJ, Brazil. ${ }^{2}$ Instituto D'Or de Pesquisa e Ensino (IDOR), Rio de Janeiro, RJ, Brazil. ${ }^{3}$ Institute of Psychiatry, Psychology and Neuroscience, King's College, London, UK. Submitted Sep 11 2017, accepted for publication Apr 182018.

Suggested citation: Figueiredo T, Erthal P, Fortes D, Asherson P, Mattos P. Transcultural adaptation to Portuguese of the Mind Excessively Wandering Scale (MEWS) for evaluation of thought activity. Trends Psychiatry Psychother. 2018;40(4):337-341. Epub Sep 17 2018. http://dx.doi.org/10.1590/2237-6089-2017-0117
} 


\section{Introduction}

Mind wandering can be translated in a literal sense into Portuguese as "devaneio." The original concept of this term encompasses the idea of periods in which attention and content of thoughts depart from the original idea or the activity being performed at the moment these thoughts occur. ${ }^{1}$ This experience can be considered universal, often experienced by any individual, without necessarily translating a pathological symptom. It is estimated that around 24 to $50 \%$ of the waking time is involved with thoughts that are not directly related to the task performed at the moment.1,2

Mind wandering is currently classified into two subtypes: spontaneous and deliberate. ${ }^{3}$ The first refers to the displacement of thinking during the execution of an activity that requires attention maintenance (for example during a lesson, a conversation or during studies). The deliberate subtype, however, refers to the practice of deliberately or intentionally shifting thoughts. For example, when planning what to do at dinner while driving a vehicle, or planning work activities while performing an unrelated task. It is important to emphasize that the intensity and frequency with which mind wandering occurs is the main evaluation criterion to determine any impairment entailed by its excess. The spontaneous subtype, when occurring in excessive frequency and intensity, is often related to psychiatric disorders, in particular attention deficit hyperactivity disorder (ADHD). ${ }^{4}$ ADHD is a neurodevelopmental disorder, characterized by symptoms of inattention, hyperactivity and impulsivity. ${ }^{5}$ It is the most common psychiatric disorder in childhood; in approximately $60 \%$ of cases, symptoms persist in adulthood. ${ }^{6}$ It is estimated that about $2.5 \%$ of adults have ADHD. ${ }^{7}$

Although the diagnosis of ADHD is based solely on reports of inattention, hyperactivity and impulsivity, there are extensive reports in the literature regarding ceaseless thought activity (thoughts in constant motion), sensations of difficulty in controlling one's own thoughts and reports of different thoughts unrelated to the activity being performed.4,8 Apparently, the inattentive behavior in ADHD is directly related to the excess and intensity of mind wandering.

In 2016, Mowlem et al. validated the Mind Wandering Excessively Scale (MEWS), with great potential to measure this symptomatic dimension. Items from the scale are scored on a 4-point Likert-type scale ( $0=$ not at all or rarely; $1=$ some of the time; $2=$ most of the time; 3 = nearly all of the time or constantly). The scale was administered to adult patients diagnosed with ADHD and showed statistically significant internal consistency, sensitivity and specificity in the diagnosis of ADHD. ${ }^{3}$
In addition, the scale allowed to distinguish between ADHD and controls, with good psychometric properties: good internal consistency ( $a>0.9$ ), high sensitivity (0.9) and specificity (0.9) for the ADHD diagnosis. Eigenvalues indicated a unidimensional structure to the MEWS; Cronbach's alpha coefficients were higher than all comparable existing instruments for ADHD diagnosis. The preliminary scale had 15 items, which were then changed to 12 after psychometric analysis. The suggested cut-off was $15 .^{3}$ Mind wandering has not been investigated in other psychiatric disorders, with the single exception of major depression ${ }^{9,10}$; in addition, there are no studies in languages other than English.

The main objective of this study was to perform a cross-cultural adaptation of the MEWS into Brazilian Portuguese.

\section{Methods}

This study was part of a larger study on ADHD, approved by the ethics committee of Hospital Copa D'Or (CAAE 05089412220025249). The authors followed general guidelines of the method proposed by Herdman et al. ${ }^{11}$ The process of cross-cultural adaptation occurred in five consecutive steps: a) step 1, translation of the original instrument; b) step 2, back-translation; c) step 3, formal appreciation of equivalence; d) step 4, debriefing with a convenience sample; and e) step 5, final criticism by experts in the field.

Step 1 consisted of two translations of the original scale in English into Brazilian Portuguese, performed independently. The first one (T1) was carried out by a qualified professional in Letters and with specialization in English, and the second (T2) by a psychiatrist with experience in ADHD and fluent in the English language, able to identify the concept that sustains each of the items of the original instrument. In this step, operational equivalence was respected, aiming to maintain original characteristics, keeping the same number of items (12), the same statement and the same four frequency response options.

Step 2 consisted of backward translations of T1 and T2 into English, respectively by another professional in Letters (R1) and a psychologist with experience in ADHD and fluent in the English language (R2). Both backtranslations occurred independently, and both backtranslators were blind to the profile of the professionals involved in the first stage.

Step 3 involved the formal appreciation of semantic equivalence with professionals with the same profile as in previous steps. For the judgment of semantic equivalence, the general and referential meanings of the terms and 
expressions of each of the 12 items were evaluated. Referential meanings refer to the literal correspondence between words in the original scale and the backtranslations. General meanings refer to the concepts to which a single word or a set of words allude, considering aspects more subtle than the literal equivalence. That is, in semantic equivalence, we consider not only the meaning of the words between the two languages, but also try to achieve the same effect that the items have in different cultures. The evaluation of semantic equivalence was done by structuring a form in which the items and their back-translations were arranged in pairs (T1-R1; T2-R2). Professionals scored the equivalence in four levels: unchanged; changed a little; greatly changed; and completely changed. After joint assessment and discussion, a synthesis-based version was prepared based on the evaluation and judgment of all scale items. Five professionals with extensive clinical experience in ADHD (psychiatrists and psychologists), who did not participate in the previous stages, from distinct university institutions, received the synthesis version to comment and critique, based on clinical experience. The author of the original instrument was accessed to clarify doubts about the original idea of each item. From this work, a new synthesis version was elaborated considering the contributions after discussion with all involved.

Subsequently, in step 4, the synthesis version was administered to a convenience sample comprising 20 adult controls and 20 patients diagnosed with adult ADHD, with no relevant axis-I disorder. The sociodemographic data of the subjects evaluated are presented in the Table 1 . Patients were recruited among individuals referred for neuropsychological testing at Centro de Neuropsicologia Aplicada, at Instituto D'Or de Pesquisa e Ensino (IDOR), in Rio de Janeiro. They were diagnosed by experienced psychiatrists in accordance to criteria from the Diagnostic and Statistical Manual of Mental Disorders, 5th edition (DSM-5). All individuals signed an informed consent form. Adults of both sexes were involved and all individuals either had at least college level or were attending college. In order to comply with this step, each respondent was asked to answer the MEWS and provide real-life examples. They were also asked to report any difficulty in understanding the items; all comments were registered.

Step 5 consisted of the collection and discussion of comments from step 4 by the same professionals involved in step 3 .

\section{Results}

Table 2 presents examples from steps 1, 2, and 3 for five MEWS items that were considered the most difficult ones to translate. The two translations of the scale ( $\mathrm{T} 1$ and T2) had good measures of semantic equivalence to the original instrument. No items were rated as completely changed. Two items were classified as greatly changed and required further discussion in step 3. For this reason, a third translation was proposed (T3). This last translation included modifications in order to make items more easily understood by individuals in a broader range of schooling levels, without changing the intended sense of each item. All items modified in T3 were evaluated by the original author of the instrument so that the intended meaning remained unchanged. The expressions "in a fog," "on the go" and "switch thoughts off" were replaced with a colloquial equivalent judged to be more easily understood, conveying in a coherent way what was intended to be evaluated. In addition, some grammatical restructuring was undertaken to make items more clear and concise.

Steps 4 and 5 contributed to the evaluation of possible difficulties during the administration of the scale. Items 5 and 6 were considered to be somewhat similar by some patients and we discussed this information with the scale author (PA). However, no changes were suggested for the final version (Table 3 ).

Table 1 - Demographic characteristics

\begin{tabular}{|c|c|c|}
\hline Variable & Diagnosed with ADHD $(\mathrm{N}=20)$ & Controls $(\mathrm{N}=20)$ \\
\hline Male, n (\%) & $13(65)$ & $11(55)$ \\
\hline Age, mean & 29.8 & 32.1 \\
\hline \multicolumn{3}{|l|}{ Education, n (\%) } \\
\hline Attending college & $5(25)$ & $6(30)$ \\
\hline Graduate & $11(55)$ & $8(40)$ \\
\hline Postgraduate & $4(20)$ & $6(30)$ \\
\hline Employed, $\mathrm{n}$ & 19 & 20 \\
\hline
\end{tabular}


Table 2 - Examples of items in the Mind Excessively Wandering Scale (MEWS): translations (T1 and T2), back-translations (R1 and R2) and synthesis version

\begin{tabular}{|c|c|c|c|c|c|}
\hline Original version & T1 & $\mathbf{R 1}$ & T2 & $\mathbf{R 2}$ & Final version \\
\hline $\begin{array}{l}\text { I have difficulty } \\
\text { controlling my thoughts }\end{array}$ & $\begin{array}{l}\text { Eu tenho dificuldade } \\
\text { em controlar meus } \\
\text { pensamentos }\end{array}$ & $\begin{array}{l}\text { I have difficulty } \\
\text { in controlling my } \\
\text { thoughts }\end{array}$ & $\begin{array}{l}\text { Eu tenho dificuldade } \\
\text { para controlar meus } \\
\text { pensamentos }\end{array}$ & $\begin{array}{l}\text { I find it difficult to } \\
\text { control my thoughts }\end{array}$ & $\begin{array}{l}\text { Eu tenho dificuldade } \\
\text { de controlar meus } \\
\text { pensamentos }\end{array}$ \\
\hline $\begin{array}{l}\text { I find it hard to switch } \\
\text { my thoughts off }\end{array}$ & $\begin{array}{l}\text { Eu acho difícil } \\
\text { "desligar" meus } \\
\text { pensamentos }\end{array}$ & $\begin{array}{l}\text { I think it's hard } \\
\text { to "turn off" my } \\
\text { thoughts }\end{array}$ & $\begin{array}{l}\text { Eu acho difícil parar } \\
\text { de pensar }\end{array}$ & $\begin{array}{l}\text { I find it hard to stop } \\
\text { thinking. }\end{array}$ & $\begin{array}{l}\text { Eu acho difícil ficar } \\
\text { sem pensar em } \\
\text { nada }\end{array}$ \\
\hline $\begin{array}{l}\text { My thoughts are 'on the } \\
\text { go' all the time }\end{array}$ & $\begin{array}{l}\text { Meus pensamentos } \\
\text { estão em } \\
\text { movimento o tempo } \\
\text { todo }\end{array}$ & $\begin{array}{l}\text { My thoughts are in } \\
\text { movement all the } \\
\text { time }\end{array}$ & $\begin{array}{l}\text { Meus pensamentos } \\
\text { estão em atividade } \\
\text { o tempo todo }\end{array}$ & $\begin{array}{l}\text { I am constantly } \\
\text { thinking. }\end{array}$ & $\begin{array}{l}\text { Meus pensamentos } \\
\text { estão sempre ativos }\end{array}$ \\
\hline $\begin{array}{l}\text { I find it difficult to think } \\
\text { clearly, as if my mind is } \\
\text { in a fog }\end{array}$ & $\begin{array}{l}\text { Eu acho difícil } \\
\text { pensar com clareza, } \\
\text { como se minha } \\
\text { mente estivesse } \\
\text { nublada }\end{array}$ & $\begin{array}{l}\text { I find it hard to } \\
\text { think clearly, as } \\
\text { if my mind were } \\
\text { cloudy }\end{array}$ & $\begin{array}{l}\text { Eu tenho dificuldade } \\
\text { para pensar de } \\
\text { modo claro, como } \\
\text { se minha mente } \\
\text { estivesse numa } \\
\text { névoa }\end{array}$ & $\begin{array}{l}\text { It is hard for me to } \\
\text { think clearly, as if } \\
\text { my mind was foggy. }\end{array}$ & $\begin{array}{l}\text { Eu tenho dificuldade } \\
\text { de pensar de uma } \\
\text { forma clara, é como } \\
\text { se minha cabeça } \\
\text { estivesse "confusa" }\end{array}$ \\
\hline $\begin{array}{l}\text { I can only focus my } \\
\text { thoughts on one thing at } \\
\text { a time with considerable } \\
\text { effort }\end{array}$ & $\begin{array}{l}\text { Eu só consigo } \\
\text { concentrar meus } \\
\text { pensamentos em } \\
\text { uma coisa de cada } \\
\text { vez com esforço } \\
\text { considerável }\end{array}$ & $\begin{array}{l}\text { I can only } \\
\text { concentrate my } \\
\text { thoughts on one } \\
\text { thing at time with } \\
\text { considerable effort }\end{array}$ & $\begin{array}{l}\text { Eu só consigo } \\
\text { concentrar meus } \\
\text { pensamentos numa } \\
\text { coisa de cada vez } \\
\text { se fizer muito } \\
\text { esforço }\end{array}$ & $\begin{array}{l}\text { I can only } \\
\text { concentrate my } \\
\text { thoughts on one } \\
\text { thing at a time if I } \\
\text { make a great effort. }\end{array}$ & $\begin{array}{l}\text { Eu preciso fazer } \\
\text { muito esforço para } \\
\text { me concentrar em } \\
\text { uma coisa de cada } \\
\text { vez }\end{array}$ \\
\hline
\end{tabular}

Table 3 - Mind Wandering Excessively Scale, final version in Portuguese

\begin{tabular}{|c|c|c|c|c|c|}
\hline Itens & & $\begin{array}{l}\text { Nem um pouco } \\
\text { ou raramente }\end{array}$ & $\begin{array}{l}\text { Uma parte } \\
\text { do tempo }\end{array}$ & $\begin{array}{l}\text { A maior parte } \\
\text { do tempo }\end{array}$ & $\begin{array}{l}\text { Quase o tempo todo } \\
\text { ou constantemente }\end{array}$ \\
\hline 1. & $\begin{array}{l}\text { Eu tenho dificuldade de controlar meus } \\
\text { pensamentos }\end{array}$ & 0 & 1 & 2 & 3 \\
\hline 2. & Eu acho difícil ficar sem pensar em nada & 0 & 1 & 2 & 3 \\
\hline 3. & $\begin{array}{l}\text { Eu tenho dois ou mais pensamentos diferentes } \\
\text { ocorrendo ao mesmo tempo }\end{array}$ & 0 & 1 & 2 & 3 \\
\hline 4. & $\begin{array}{l}\text { Meus pensamentos são desorganizados ou } \\
\text { bagunçados }\end{array}$ & 0 & 1 & 2 & 3 \\
\hline 5. & Meus pensamentos estão sempre ativos & 0 & 1 & 2 & 3 \\
\hline 6. & Eu sinto que a minha mente não para & 0 & 1 & 2 & 3 \\
\hline 7. & $\begin{array}{l}\text { Eu acho difícil pensar numa coisa sem que outra } \\
\text { me venha à mente }\end{array}$ & 0 & 1 & 2 & 3 \\
\hline 8. & $\begin{array}{l}\text { Meus pensamentos me distraem e me impedem } \\
\text { de me concentrar no que estou fazendo }\end{array}$ & 0 & 1 & 2 & 3 \\
\hline 9. & $\begin{array}{l}\text { Eu tenho dificuldade de desacelerar meu } \\
\text { pensamento para me concentrar em uma coisa } \\
\text { de cada vez }\end{array}$ & 0 & 1 & 2 & 3 \\
\hline 10 & $\begin{array}{l}\text { Eu tenho dificuldade de pensar de uma forma } \\
\text { clara, é como se minha cabeça estivesse } \\
\text { "confusa" }\end{array}$ & 0 & 1 & 2 & 3 \\
\hline 11. & $\begin{array}{l}\text { Eu me vejo indo e voltando entre diferentes } \\
\text { pensamentos }\end{array}$ & 0 & 1 & 2 & 3 \\
\hline 12. & $\begin{array}{l}\text { Eu preciso fazer muito esforço para me } \\
\text { concentrar em uma coisa de cada vez }\end{array}$ & 0 & 1 & 2 & 3 \\
\hline
\end{tabular}




\section{Discussion}

Mind wandering refers to a universal phenomenon that occurs in any individual's daily productive time, even in a healthy population. However, its intensity and frequency appear to be directly related to the functional impairment occurring in some psychiatric disorders, especially ADHD. Nevertheless, the symptomatic characteristics of ADHD change according to the age group of the individuals. In the child, main symptoms are difficulty in sustaining attention and hyperactivity. In the adult, hyperactivity is no longer a central symptom of the disease, with symptoms of inattention and restlessness/impulsivity prevailing. ${ }^{12}$

There are few instruments available for use in clinical practice to measure the activity of thought in more detail. The characteristics of mental activity (thoughts) constitute one of the main distracting factors in ADHD. Thoughts occurring at the same time, a sense of ceaseless thought activity and difficulty in focusing on just one task are characteristic of the wandering mind that in turn relate to negative outcomes such as difficulties in completing a task (including requiring more time to do it), difficulties in relaxing during free time and difficulties in starting to sleep.

Inventories based on the DSM-5 diagnostic criteria fail to detail thought activity in ADHD patients; questions addressing inattention evaluate this domain in a more general way. In addition, a specific tool to assess thought activity would be welcome during treatment evaluation; one study has demonstrated a positive response with psychostimulants and the practice of mindfulness. ${ }^{13}$ The MEWS has the potential to allow the development of more research on mind wandering, a symptom that is not specifically addressed in current DSM-5 criteria for any disorder. Mind wandering investigation might be particularly important in ADHD, where it is strongly related to impairment. ${ }^{3}$

\section{Limitations}

This study aimed to translate and adapt a foreign instrument into Brazilian Portuguese. Psychometric properties of the scale were not investigated and prompt future studies with patient samples in which mind wandering is an important symptom.

\section{Disclosure}

Paulo Mattos is on the Advisory Board of Shire and has received travel grants to participate in scientific meetings. No other conflicts of interest declared concerning the publication of this article.

\section{References}

1. Smallwood J, Schooler JW. The science of mind wandering: Empirically navigating the stream of consciousness. Annu Rev Psychol. 2015;66:487-518.

2. Kane MJ, Brown LH, McVay JC, Silvia PJ, Myin-Germeys I, Kwapil TR. For whom the mind wanders, and when: an experiencesampling study of working memory and executive control in daily life. Psychol Sci. 2007;18:614-21.

3. Mowlem FD, Skirrow C, Reid P, Maltezos S, Nijjar Sk, Merwood $A$, et al. Validation of Mind Excessively Wandering Scale and the relationship of mind wandering to impairment in adult ADHD. J Atten Disord. 2016 Jun 2. pii: 1087054716651927. [Epub ahead of print].

4. Asherson, P. Clinical assessment and treatment of attention deficit hyperactivity disorder in adults. Expert Rev Neurother. 2005;5:525-39.

5. American Psychiatry Association. Diagnostic and statistical manual of mental disorders, 5th edition (DSM-5). Washington: APA; 2013.

6. Kessler RC, Adler L, Ames M, Demler O, Faraone S, Hiripi E, et al. The World Health Organization Adult ADHD Self-Report Scale (ASRS): a short screening scale for use in the general population. Psychol Med. 2005;35:245-56.

7. Polanczyk G, de Lima MS, Horta BL, Biederman J, Rohde LA. The worldwide prevalence of ADHD: a systematic review and metaregression analysis. Am J Psychiatry. 2007;164:942-8.

8. Weyandt LL, Iwaszuk W, Fulton K, Ollerton M, Beatty N, Fouts $\mathrm{H}$, et al. The internal restlessness scale: performance of college students with and without ADHD. J Learn Disabil. 2003;36:3829.

9. Konjedi S, Maleeh R. A closer look at the relationship between default network, mind wandering, negative mood, and depression. Cogn Affect Behav Neurosci. 2017;17:697-711.

10. Marchetti I, Koster EHW, Klinger E, Alloy LB. Spontaneous thought and vulnerability to mood disorders: the dark side of the wandering mind. Clin Psychol Sci. 2016;4:835-57.

11. Herdman M, Fox-Rushby J, Badia X. A model of equivalence in the cultural adaptation of HRQoL instruments: the universalist approach. Qual Life Res. 1998;7:323-35.

12. Agnew-Blais J, Polanczyk G, Danese A, Wertz J, Moffitt TE, Arseneault L. Evaluation of the persistence, remission, and emergence of attention-deficit/hyperactivity disorder in young adulthood. JAMA Psychiatry. 2016;73:713-20.

13. Xu M, Purdon C, Seli P, Smilek D. Mindfulness and mind wandering: the protective effects brief meditation in anxious individuals. Conscious Cogn. 2017;51:157-65.

\section{Correspondence:}

Tiago Figueiredo

Rua Venceslau Bras, 71

2290-140 - Rio de Janeiro, RJ - Brazil

E-mail: tiagofigueiredosf@gmail.com 